\title{
International Students' Expectations and Perceptions of Service Quality: The Case of a Higher Education Institution in South Africa
}

\author{
*Jeevarathnam P Govender, Dayaneethie Veerasamy, Dion T Noel \\ Durban University of Technology, Durban, South Africa \\ *govendej@dut.ac.za
}

\begin{abstract}
South Africa has recently seen a significant increase in international student enrolments in recent years. In order to be competitive, attention needs to be given to service quality with a view to being the institution of preference. This paper therefore seeks to assess international students' expectations and perceptions of service quality. A census was conducted among the 215 international students, using the SERVQUAL model as the measuring instrument. The results indicate that there are gaps between international students' expectations and perceptions on the five service quality dimensions. An analysis of variance was conducted to test for significant differences between three biographical variables viz. faculty of study, qualification enrolled for and region of residence versus the five dimensions of service quality, on both expectations and perceptions. Recommendations are presented on how the institution can enhance service quality among its international students.
\end{abstract}

Keywords: Service quality, international students, expectations of service, perceptions of service

\section{Introduction}

The number of foreign students enrolled at South African institutions has increased steadily from 34770 in 1999 to 47000 in 2003 (World Education News and Reviews, 2004). With this significant increase in the number of international students, the challenge is to ascertain the expectations and perceptions of services offered to this group of students. According to Quinn, Lemay, Larsen and Johnson (2009), the measurement of customer satisfaction at an educational institution might be regarded as one of the greatest challenges of the quality movement. In pursuit of excellence, it has become more important to identify customer values and demands. The one such demand that has been identified is service quality (Jain, Sinha and Sahney, 2011). Sharma and Kaur (2004) believe that the globalisation of higher education leaves no option for educational institutions, but to improve service quality. According to Seymour (1992), higher education is being driven towards a commercially based competition brought about by economic forces. Associated with this, Jain, et al (2011) believe that this competition is a consequence of the growth of the global education market on the one hand, and the curtailment in state funding on the other, making it necessary for educational institutions to seek other sources of income. Stone (2005) suggests that given the highly competitive education market, students have become more discerning in their selection and more demanding of their institution of choice. It is therefore important that institutions are optimistic, hence the need for constant research into service quality with a view to quality improvement. Given the importance of higher education in emerging economies such as South Africa, and having an understanding of the competition that exists in this sector, research into the measurement of service quality in higher education becomes justified. This paper therefore aims to examine the expectations and perceptions of international students of service quality. Specifically, it seeks to identify gaps between expectations and perceptions of service quality, and to examine relationships between selected biographical variables and international students' expectations and perceptions of service quality. Though limited to one higher education institution in South Africa, this paper will be of interest and relevance to other higher education institutions, in not only South Africa, but also other developing countries. The outcome of the study would be beneficial for management to identify shortcomings in service quality and continuously improve the quality of education as expected by the target market, viz. students.

\section{Literature Review}

The meaning and attributes of service quality: Quality is described as the measurement of how well the product or service of the organisation conforms to the customers' wants and expectations. Quality is the ability of the organisation to meet or exceed customer expectations (Brink \& Berndt, 2010). 
According to Lovelock \& Wright (2007), after making a purchase, customers compare the service expected to what is actually received. Customers decide how satisfied they are with service delivery and outcomes, and they become judgemental regarding quality. Futrell (2008) believes that service quality from an organisation's perspective means establishing requirements and specifications. If organizations want a satisfied customer to continue with the service, the former must provide an excellent level of service quality. Zeithaml, Bitner and Gremler (2006) state that services cannot be stored, saved, resold or returned. Customers' perception of the quality of service that one offers is what determines success (Quintana, 2006). According to Dhurup, Singh and Surujlal (2006), unlike conventional business products, services provided by higher education institutions are intangible and highly subjective and students look for evidence of service quality to reduce uncertainty. Armstrong and Kotler (2006) suggest that in reducing uncertainty, buyers seek certain conclusions of service quality from the place, people, equipment, and communications they receive from the service provider. The basis for measurement of service quality in this study is the SERVQUAL model. The SERVQUAL model is based on the premise that customers evaluate service quality by comparing expectations of service with perceptions of service (Lovelock and Wirtz, 2007). These are briefly covered in the sections that follow.

Customer expectations of service: Zeithaml et al. (2006) are of the opinion that expectations are beliefs about service delivery that serve as standards against which performance is judged. Customer expectations are critical to service marketers and will deeply influence customer behaviour. Customer expectations are not stable and are human preconceptions based on verbal information, personal needs, experience and commercial information. Harris (2010) believes that every customer walks into a known or unknown, with a set of expectations. According to Coye (2004), the concept of expectations plays an important role in assessing service quality.

Customer perceptions of service: Strydom, Jooste and Cant (2000) define customer perception as the process of receiving, organising and assigning meaning to information or stimuli detected by the customer's five senses and believe that it gives meaning to the world that surrounds the customer. Silvestro (2005) states that the only criteria that count in evaluating service quality are those defined by the customer. Cultural differences will also affect the relative importance placed on the elements of service quality. Customers do not perceive quality in a one-dimensional way, but rather judge quality on multiple factors relevant to the context (Zeithaml et al., 2006). Based on the SERVQUAL model, customer expectations and perceptions are measured based on five dimensions. These are briefly explained.

The dimensions of service quality: Dhurup et al. (2006), identify five factors that can influence the quality of a service encounter in a service setting viz. tangibles, reliability, responsiveness, assurance and empathy:

Tangibles: Brink and Berndt (2010), classify tangibles in terms of the facilities, equipment and material, which must reflect positively on the organisation. The dimension also includes the appearance of employees. The challenge for institutions is to ensure that service specifications such as course content, delivery and application meet the expectations of their customers consistently.

Reliability: Reliability refers to the ability to perform service dependably and accurately. According to Yeo (2008), discrepancy between promise and delivery is largely the result of inaccurate communication from advertisement and exhibitions. Some institutions tend to oversell their services, leading to grand promises that misrepresent their actual potential and academic readiness.

Responsiveness: Responsiveness relates to the willingness to help and respond to customers' needs. Institutions of higher learning should be responsive to the shifting needs of their students in providing courses and training programmes that are relevant in subject matter and teaching approaches (Yeo, 2008). Dale, Van der Wiele and Van Iwaarden (2007) state that responsiveness includes the willingness to assist customers and to provide prompt service on a continuous basis including attentiveness and willingness in dealing with customer requests, queries and prompt complaint resolution.

Assurance: The assurance dimension focuses on the ability of staff to inspire confidence and trust. Judgement of high or low service quality largely depends on how the customers perceive the actual performance based on their expectation. The availability of choices should diversify the expectation 
levels of customers in a way that the shortcomings of one service can be offset by the strengths of another (Yeo, 2008).

Empathy: Empathy refers to the extent to which caring individualised service is given. It is sometimes a challenge for institutions to exceed customer expectations and demand. For instance, shortages of teaching staff and the need for optimal enrolments have seen an increase in class sizes, stretching the lecturer-student ratio. Furthermore, when lecturers are expected to assume multiple roles, the level of service quality may become less standardized and desirable over time (Yeo, 2008). Finally, it is important to show the link between service quality and customer satisfaction.

Service quality and customer satisfaction: The marketing concept has proven that companies do not have to sacrifice profitability to keep customers happy. Organisations, which consistently rank high on customer satisfaction, also rank high in profitability (Blem, 2000). Many positive links have been observed between customer satisfaction, loyalty and the propensity to recommend the supplier's product to other customers. Satisfaction can be conceptualised as a state of mind that can constantly change and be reassessed over the encounter, or a series of encounters, and is not static even within one encounter (Gabbott and Hogg, 2002).

\section{Methodology}

The study is descriptive, cross sectional and quantitative in nature. The SERVQUAL instrument, pioneered by Parasuramen, Zeithaml and Berry (1985) was used to measure respondents' expectation and perception of service quality, using twenty items that cover the five dimensions of service quality identified in the literature review. A five-point Likert scale (strongly disagree - strongly agree) was used. For the purposes of this study, an attempted census was conducted because of the relatively small population of 215. According to Brown and Suter (2008), a census is a type of sampling plan where data is collected from or about every member of a population. A census is appropriate if the population size itself is quite small (Aaker, Kumar and Day, 2007; Malhotra, 2007). Hence, the survey was conducted among all international students enrolled at the institution. A listing of international students was obtained, indicating a population size of 215 . The questionnaires were personally administered with the use of fieldwork assistants. According to Sekaran (2003), for a population of 215, a sample size of 192 is considered statistically acceptable at the 95\% level of significance. The response rate of 191 was therefore considered appropriate in order to draw inferences. The data was analysed using the SPSS statistical package (Version 15). Reliability was assessed by means of Cronbach Alpha.

\section{Results}

\section{Biographical characteristics of respondents}

Faculty of study: As reflected in Table 1, 1\% of respondents were in the faculty of Health Sciences, followed by $4 \%$ being in Arts and Design, 11\% in Accounting and Informatics, $18 \%$ in Applied Sciences, $20 \%$ in Management Sciences and 47\% being in Engineering and the Built Environment.

Qualification of enrolment: As indicated in Table 1,66\% of the respondents were enrolled for a National diploma, $22 \%$ were enrolled for a Bachelor of Technology degree, followed by $4 \%$ being enrolled for a

Region of residence: It emerged that there were six segments in terms of region of residence. $67 \%$ of respondents were from Africa, 15\% from Asia, 13\% from Europe, 3\% from South America and 2\% from other countries. The results are reflected in Table 1.

Test for normality: The results of the One-Sample Kolmogorov test show that the data was not normally distributed, hence non-parametric testing being used (Aaker, Kumar and Day, 2007). A Kruskal-Wallis Analysis of variance (ANOVA) was used to determine differences in means between the categories of the biographical variables.

Assessing reliability: In assessing reliability, the Cronbach alpha test indicated a score of 0.916 and 0.901 for the expectations and perceptions dimensions respectively. This suggests a high degree of inter-item consistency among the items (Malhotra, 2007). 
SERVQUAL Gap scores: A profile of the expectations and perceptions of the service quality dimensions as well as the rankings are presented in Table 2. The empathy dimension reflects the highest gap score (1.14) implying that it needs to be accorded the highest priority with regard to the improvement of service quality, followed by assurance and responsiveness, with tangibles and reliability being equal and having the lowest gap score. Arambewela \& Hall (2006) found that students considered tangibles as an extremely important dimension in assessing service quality at universities. These findings concur with those of Wakefield \& Blodgett (1999). The mean GAP score of -0.87 indicates that the perceptions of respondents do not meet with their expectations of overall service quality at the company.

Table 1: Biographical detail of Respondents

\begin{tabular}{lc}
\hline Respondents & $\mathbf{0}$ \\
\hline Faculty of study & \\
Health Sciences & 1 \\
Art \& Design & 4 \\
Accounting \& Informatics & 11 \\
Applied Sciences & 18 \\
Management Sciences & 20 \\
Engineering \& the Built Environment & 47 \\
Total & 100 \\
Qualification of enrolment & \\
National diploma & 66 \\
Bachelor of Technology & 22 \\
Master of Technology & 4 \\
Doctor of Technology & 8 \\
Total & 100 \\
Region of residence & \\
Africa & 67 \\
Asia & 15 \\
Europe & 13 \\
South America & 3 \\
Other & 2 \\
Total & 100 \\
\hline
\end{tabular}

Master of Technology degree and 8\% of respondents studying towards a Doctor of Technology degree.

Table 2: SERVQUAL GAP Scores

\begin{tabular}{lllll}
\hline Dimension & Expectation(E) & Perception(P) & Score(P-E) & Rank \\
\hline Tangibles & 4.33 & 3.64 & -0.69 & 4 \\
Reliability & 4.38 & 3.69 & -0.69 & 4 \\
Responsiveness & 4.46 & 3.64 & -0.82 & 3 \\
Assurance & 4.50 & 3.52 & -0.98 & 2 \\
Empathy & 4.47 & 3.33 & -1.14 & 1 \\
Mean & 4.43 & 3.56 & -0.87 & \\
\hline
\end{tabular}

Comparison between faculties: Table 3 reflects the results of the Kruskal-Wallis ANOVA used to make comparisons between faculties. Since there was only one student from Health Sciences, this faculty was excluded from this analysis.

The results indicate a significant difference in the empathy scores between faculties at the $95 \%$ level $(\mathrm{p}<0.05)$. The mean score for empathy-perceptions was lowest for the faculty of Art \& Design. There were no significant differences among faculties for the other four expectations and perceptions dimensions.

Table 4 reflects the results of the comparison of mean scores between qualifications of enrolment. Expectation relating to the assurance and empathy dimensions were significantly different between qualifications at the $95 \%$ level $(\mathrm{p}<0.05)$. There were no significant differences among the qualifications with regard to the remaining dimensions of expectations and perceptions. 
Table 3: Comparison of means between faculties

\begin{tabular}{lcccccc}
\hline & N & Mean & SD & ANOVA & df & p \\
\hline Tangibles - Expectations & 191 & 4.3320 & .52125 & .756 & 4 & .944 \\
Tangibles - Perceptions & 191 & 3.6354 & .77503 & 5.609 & 4 & .230 \\
Reliability - Expectations & 191 & 4.3841 & .51092 & 3.717 & 4 & .446 \\
Reliability - Perceptions & 191 & 3.6914 & .67502 & 4.245 & 4 & .374 \\
Responsiveness Expectations & 191 & 4.4653 & .53385 & 2.518 & 4 & .641 \\
Responsiveness - Perceptions & 191 & 3.6458 & .76775 & 2.411 & 4 & .661 \\
Assurance - Expectations & 191 & 4.5052 & .50874 & 7.676 & 4 & .104 \\
Assurance - Perceptions & 191 & 3.5208 & .71541 & 5.397 & 4 & .249 \\
Empathy - Expectations & 191 & 4.4674 & .52855 & 9.587 & 4 & $.048^{*}$ \\
Empathy - Perceptions & 191 & 3.3333 & .96480 & 10.468 & 4 & $.033^{*}$ \\
\hline
\end{tabular}

*Significant at $95 \%$ level

Comparison of means between qualifications of enrolment

Table 4: Comparison of means between qualifications of enrolment

\begin{tabular}{lllllll}
\hline & N & Mean & SD & ANOVA & df & p \\
\hline Tangibles - Expectations & 191 & 4.3325 & .52259 & 6.338 & 3 & .096 \\
Tangibles - Perceptions & 191 & 3.6335 & .77662 & 2.779 & 3 & .427 \\
Reliability - Expectations & 191 & 4.3809 & .51030 & 2.191 & 3 & .534 \\
Reliability - Perceptions & 191 & 3.6911 & .67678 & .380 & 3 & .944 \\
Responsiveness - Expectations & 191 & 4.4625 & .53384 & 4.051 & 3 & .256 \\
Responsiveness - Perceptions & 191 & 3.6492 & .76833 & 7.278 & 3 & .064 \\
Assurance - Expectations & 191 & 4.5026 & .50881 & 10.340 & 3 & $.016^{*}$ \\
Assurance - Perceptions & 191 & 3.5194 & .71701 & 3.156 & 3 & .368 \\
Empathy - Expectations & 191 & 4.4647 & .52852 & 8.470 & 3 & $.037^{*}$ \\
Empathy - Perceptions & 191 & 3.3429 & .95810 & 7.636 & 3 & .054 \\
\hline
\end{tabular}

*Significant at 95\% level

Table 5: Comparison of means between regions of residence

\begin{tabular}{lllllll}
\hline & N & Mean & SD & ANOVA & df & p \\
\hline Tangibles - Expectations & 191 & 4.3338 & .52206 & 3.817 & 4 & .431 \\
Tangibles - Perceptions & 191 & 3.6335 & .77662 & 3.775 & 4 & .437 \\
Reliability - Expectations & 191 & 4.3861 & .51150 & 3.253 & 4 & .516 \\
Reliability - Perceptions & 191 & 3.6898 & .67642 & 4.013 & 4 & .404 \\
Responsiveness - Expectations & 191 & 4.4677 & .53419 & 1.530 & 4 & .821 \\
Responsiveness - Perceptions & 191 & 3.6440 & .76934 & 9.240 & 4 & .055 \\
Assurance - Expectations & 191 & 4.5079 & .50876 & 4.456 & 4 & .348 \\
Assurance - Perceptions & 191 & 3.5183 & .71645 & 7.629 & 4 & .106 \\
Empathy - Expectations & 191 & 4.4699 & .52885 & 5.563 & 4 & .234 \\
Empathy - Perceptions & 191 & 3.3298 & .96612 & 15.075 & 4 & $.005^{*}$ \\
\hline
\end{tabular}

*Significant at $95 \%$ level 
Table 5 indicates a significant difference in mean scores for empathy-perceptions between regions at the $95 \%$ level $(\mathrm{p}<0.05)$. There were no significant differences among the regions with regard to the remaining dimensions of expectations and perceptions. Studies conducted by Arambewela \& Hall (2006) revealed a significant difference between countries of origin on all of the SERVQUAL dimensions.

\section{Conclusion}

This paper constituted an examination of international students' expectations and perceptions of service quality. The results indicate that there were gaps in terms of the five dimensions of service quality with the empathy dimension showing the largest gap score and both the tangibles and reliability dimensions showing the smallest gap scores. It emerged that there were significant differences between faculty of enrolment and expectations as well as perceptions of empathy, qualification of enrolment and expectations of assurance as well as expectations of empathy, and region of residence and perceptions of empathy. There were no significant differences between the biographic variables and the remaining expectations and perception items. Based on the research findings, it is recommended that employees must be trained in service quality-related programmes e.g. international student liaison, service improvement, product (course) knowledge, communication and interpersonal skills with a view to enhancing service quality among international students. This view is shared by Arambewela \& Hall (2006) who highlight the importance of international student advisers as a very important variable contributing to student satisfaction. Academic staff needs to be sensitised to the needs of international students in terms of, inter alia, language, study skills and culture. Management must prioritise resources when purchasing new equipment so that the facilities that customers (international students) utilize are well maintained and visually appealing. Management should ensure that appropriate feedback mechanisms are in place to check deadlines promised to international students, carrying out promises timorously as well as dedication shown by staff to solve international students' problems and generally, the learning and living environment should be conducive to the needs of international students.

\section{References}

Aaker, D. A., Kumar, V. \& Day, G.S. (2007). Marketing Research (9th Ed), Englewood Cliffs, NJ: John Wiley \& Sons.

Arambewela, R. \& Hall, J. (2006). A comparative analysis of international education satisfaction using SERVQUAL. Journal of Services Research, 6(7), 141-163.

Armstrong, G. \& Kotler, P. (2006). Marketing: An introduction ( $8^{\text {th }}$ Ed), Englewood Cliffs, NJ: Prentice-Hall International.

Blem, N. (2000). Service Please South Africa. Johannesburg: Creda Press.

Brink, A. \& Berndt, A. (2010). Customer Relationship Management and Customer Service. Johannesburg: Juta.

Brown, T. J. \& Suter, T. (2008). Marketing research. Mason: South Western-Cengage Learning

Coye, R. W. (2004). Managing customer expectations in the service encounter. International Journal of service industry management, 15(1), 54-71.

Dale, B. G., Van-der-Wiele, T. \& Van-Iwaarden, J. (2007). Managing Quality (5 ${ }^{\text {th }}$ Ed), Oxford: Blackwell Publishing.

Dhurup, M., Singh, P. C. \& Surujlal, J. (2006). Customer Service Quality at Commercial Health and Fitness Centres. South African Journal for Research in Sport, 28(2), 39-54.

Futrell, C. (2008). Fundamentals of Selling: Customers for Life through Service (10 th Ed), NY: McGraw-Hill. Gabbott, M. \& Hogg, G. (2002). Consumers and Services. Cambridge: Bookcraft (Bath) Ltd.

Griffen, H., Norton, W. \& Samuels, R. (2002). Best practice for consumer satisfaction in manufacturing firms. Sloan Management Review, 15(31), 308-329.

Harris, E. K. (2010). Customer Service: A Practical Approach (5 ${ }^{\text {th }}$ Ed), Englewood Cliffs, NJ: Prentice-Hall.

Jain, R., Sinha, G. \& Sahney, S. (2011). Conceptualising service quality in higher education. Asian Journal on Quality, 12(3), 296-314

Lovelock, C. \& Wright, L. (2007). Principles of Service Marketing and Management (5 $5^{\text {th }}$ Ed), Englewood Cliffs NJ: Pearson.

Lovelock, C. \& Wirtz, J. (2007). Services Marketing People Technology, Strategy, Englewood Cliffs NJ: Pearson.

Malhotra, N. K. (2007). Marketing research: An Applied Orientation (5 ${ }^{\text {th }}$ Ed), Englewood Cliffs NJ: Pearson. 
Parasuraman, A., Zeithaml, V. A. \& Berry, L. (1985). A conceptual model of service quality and the implications for future research. Journal of Marketing, 49(2), 41-50.

Quinn, A., Lemay, G., Larsen, P. \& Johnson, D. A. (2009). Service quality in higher education. Total Quality Management, 20(2), 139-152

Quintana, J. (2006). The greatest blind spot: Customer perception. Available at http:// www.mycustomer.com. [Accessed 10 June 2011].

Sekaran, U. (2003). Research Methods for Business: A Skill-Building Approach (4th Ed), NY: John Wiley.

Seymour, D. T. (1992). On Q: Causing Quality in Higher Education. NY: Macmillan Press.

Sharma, R. D. \& Kaur, G. (2004). Globalisation of Indian higher education. Apeejay Business Review, 5(1), 73-78.

Silvestro, R. (2005). Applying gap analysis in the health service to inform the service improvement agenda. International journal of quality and reliability management, 22(3), 215-233.

Stone, G. (2005). An educational institution's quest for service quality: Customers' perspective. Quality Assurance in Education, 13(1), 201-225

Strydom, J. W., Jooste, C. J. \& Cant, M. C. (2000). Marketing Management (4th Ed), Cape Town: Juta.

Wakefield, K. L. \& Blodgett, J. G. (1999). Customer response to intangible and tangible service factors. Psychology \& Marketing, 16(1), 1-18

World Education News and Reviews. (2004). International Enrolment Increases. Available at http://www.wes.org/eWENR/PF/04nov/pafafrica.-htm. [Accessed 9 June 2011].

Yeo, R. K. (2008). Brewing service quality in higher education. Quality assurance in education, 16(3), 266286.

Zeithaml, V. A., Bitner, M. J. \& Gremler, D. D. (2006). Services Marketing: Integrating Customer Focus across the Firm (4th Ed), NY: McGraw-Hill. 